\title{
Matrix metalloproteinase-9 expression in pterygium
}

\author{
Expressãoda metaloprotease de matriz-9nopterígio
}

\author{
Silvana Artioli Schellini ${ }^{1}$ \\ Erika Hoyama $^{2}$ \\ Deilson Elgui Oliveira ${ }^{3}$ \\ Carlos Eduardo Bacchi ${ }^{4}$ \\ Carlos Roberto Padovani ${ }^{5}$
}

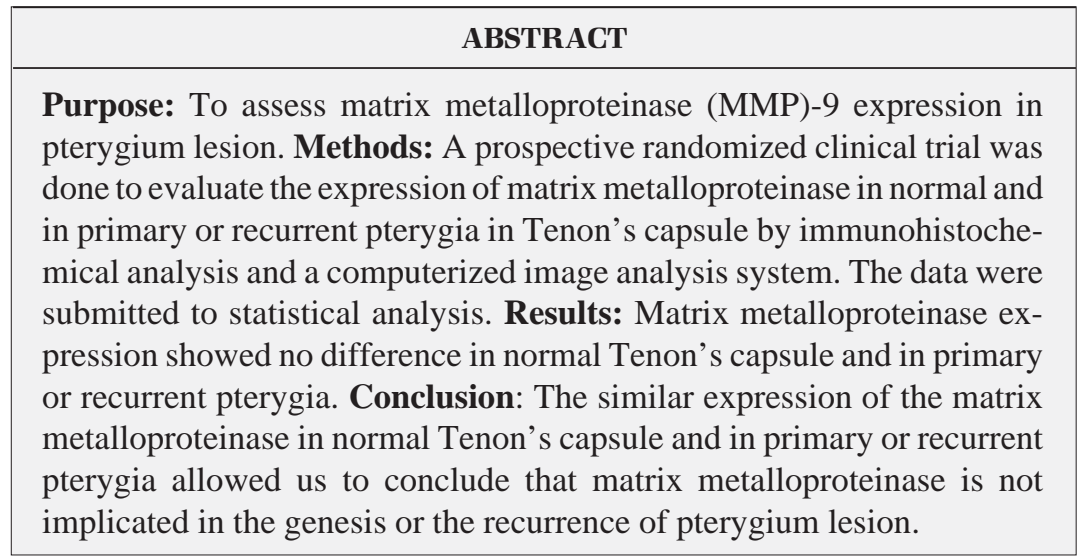

Keywords: Pterygium; Matrix metalloproteinases; Immunohistochemical/methods; Recurrence

\section{INTRODUCTION}

Matrix metalloproteinases (MMP) are a family of enzymes that act to modify or degrade the extracellular matrix components in normal and remodeling tissues and they were found in many diseases such as arthritis, tumor invasion, metastasis and angiogenesis ${ }^{(1-2)}$. These enzymes are secreted by a variety of cell types including fibroblasts and they are categorized into five groups: collagenases (MMP-1, 8, 13), gelatinases (MMP2, 9), stromelysins (MMP3, 10, 21, 22), membrane type MMPs and others ${ }^{(3)}$.

The MMPs are ubiquitous proteolytic enzymes important in physiological and pathological process, the activity of which is stringently controlled by the action of a family of natural antagonists, the tissue inhibitors of metalloproteinases (TIMPs) $)^{(4)}$.

Pterygium is a benign, fibrovascular and infiltrative process of the conjunctiva of unknown pathogenesis. The histological feature of pterygium overgrowth is excessive fibrovascular proliferation, basement membrane (Bowman's membrane) degradation and the superficial corneal stroma is invaded by the fibrovascular tissue. The degradation of the basement membrane or the extracellular matrix might be related to the extracellular proteinases or some of the MMPs ${ }^{(5)}$.

The MMP participation in the genesis of pterygium was recently suspected and overexpression of collagenases (MMP-1) and gelatinases (MMP- 2 and 9) in cultured pterygium cells ${ }^{(6)}$ or in pterygium tissue ${ }^{(7)}$ was suggested.

MMP-9 is regarded as important for degradation of the basement membrane and extracellular matrix during cancer invasion and other tissueremodeling events ${ }^{(8)}$. Thus, the purpose of this study was to evaluate the expression of MMP-9 in primary and recurrent pterygium lesion and in normal Tenon's capsule. 


\section{METHODS}

\section{Patients}

A randomized prospective clinical trial was performed at the Botucatu School of Medicine - Brazil. Sixty-one subjects presenting pterygium were submitted to surgical excision of the lesion and a fragment of normal Tenon capsule from the same eye. The age of the 61 patients ranged from 33 to 72 years (mean 51). Primary pterygium was present in 42 patients and recurrent pterygium in 19. Patients with nasal and temporal pterygium in the same eye, simultaneously, were excluded.

\section{Surgical technique}

The lesions were surgically removed after a subconjunctival infiltration of $2 \%$ lidocaine (Xylocaine) with adrenaline. A fragment of normal Tenon's capsule was removed from the inferior temporal quadrant. Then, the head of the pterygium and a portion of its body were removed with the subjacent Tenon's capsule. The conjunctiva was sutured using polygalactin 7-0.

\section{Immunohistochemical preparation}

The specimens (Tenon's capsule from pterygium and normal conjunctiva) were embedded at optimal cutting temperature and frozen at $-80^{\circ} \mathrm{C}$.

The specimens were fixed in neutral buffered formalin and embedded in paraffin. Serial 3- $\mu \mathrm{m}$ cross-sections were made and stained with hematoxylin-eosin. The fragments were placed on glass slides previously treated with poli-D-lysin adhesive (Sigma Chemical Corporation, Cat\# P-7886, MO, USA); deparaffinized in xylene and descending ethanol series and washed in buffered saline solution ( $\mathrm{pH}$ 7.4). Sections were then incubated for 15 minutes in $0.21 \%$ citrate solution $(\mathrm{pH}$ 6.4) in a microwave oven; and overnight at $4^{\circ} \mathrm{C}$ with primary monoclonal antibodies (Research Diagnostics Inc, NJ, USA):
MMP-9 1:50 (GE-213 clone, Cat\# RDI-MMP-9abm-213) was washed with buffered saline solution. ${ }^{(9)}$

\section{Quantitative MMP-9 evaluation}

The expression of MMP-9 was semiquantitative evaluated using a conventional light microscope. The expression was classified as: - (without expression), + (low expression: $<10$ stained cells per specimen), ++ (moderate expression: 10 to 20 stained cells), +++ (high expression: >20 stained cells).

The morphometric evaluation was performed using the KS 300 (Zeiss) software and a light microscope to determine the area $\left(\mathrm{mm}^{2}\right)$ of pterygium and normal conjunctiva fragments. After determining the expression of MMP-9 in each specimen, the value was divided by the total area of the material to quantify the expression rate related to the size of the specimen.

\section{Statistical analysis}

The Goodman test was used for statistical comparison of the obtained data.

\section{RESULTS}

Tenon's capsule from pterygium and normal conjunctiva had similar expression of MMP-9 (Figure 1) when the MMP-9 expression was evaluated according to the total tissue area (Table 1). Also, there was observed similarity of expression between the primary and the recurrent pterygium (Table 2).

\section{DISCUSSION}

There are many described MMP but it is still not known if or which one is involved in pterygium pathogenesis. The collagenases and gelatinases may contribute to the development of ocular surface diseases ${ }^{(10-11)}$.

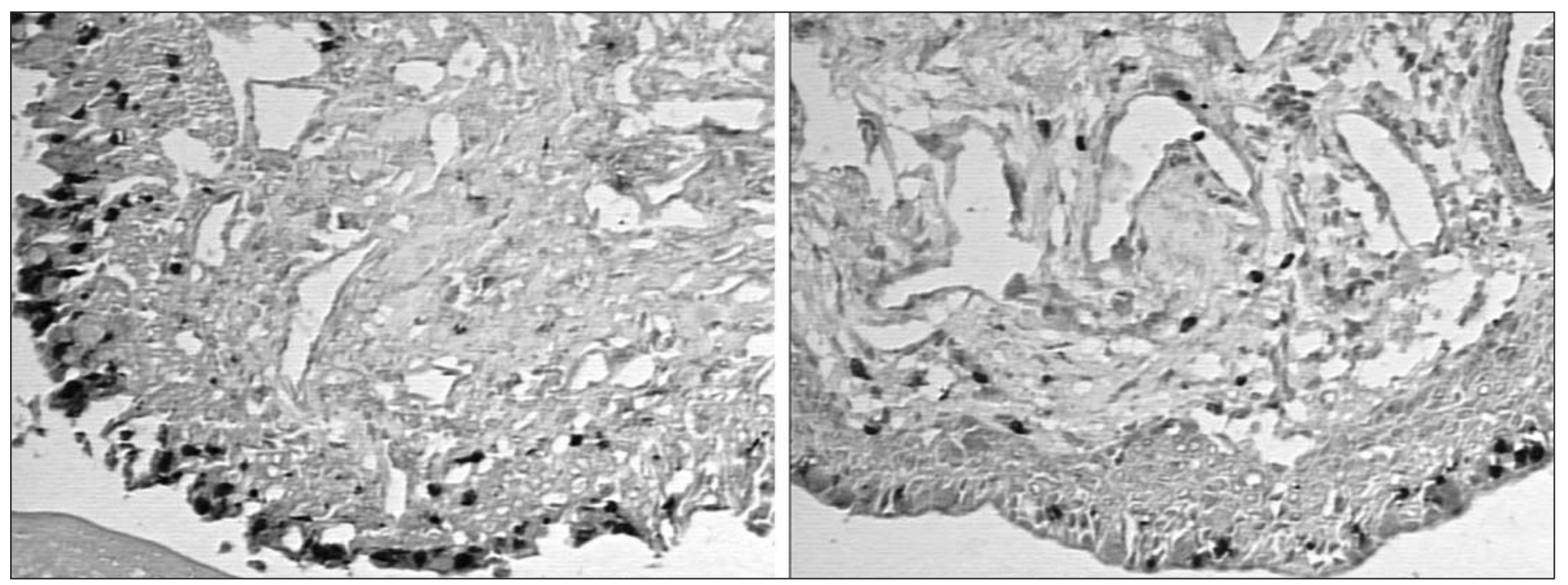

Figure 1 - MMP-9 expression in the pterygium lesion (left) and normal conjunctival tissue (right). X200 - Faculdade de Medicina de Botucatu 


\begin{tabular}{|c|c|c|c|}
\hline \multirow[b]{2}{*}{ Variable } & \multicolumn{2}{|c|}{ Tenon capsule } & \multirow{2}{*}{$\begin{array}{l}\text { Statistical } \\
\text { results }\end{array}$} \\
\hline & Normal & Pterygium & \\
\hline $\begin{array}{l}\text { Total area } \\
\text { (TA) }\end{array}$ & $5476.4 \pm 2476.3$ & $10398.0 \pm 3379.3$ & $5.8(P<0.0001)$ \\
\hline MMP-9 & $21.0 \pm 18.0$ & $23.0 \pm 23.0$ & $0.5(P>0.05)$ \\
\hline MMP-9/TA & $0.004 \pm 0.003$ & $0.002 \pm 0.003$ & $2.1(P<0.05)$ \\
\hline
\end{tabular}

MMP-9 or gelatinase B was the focus of this study because collagen type IV, the major component of the basal membrane is degraded by MMP-9 and collagen type IV is increased at the margin of the pterygium where degradation of the corneal Bowman membrane occurs ${ }^{(7)}$.

Also, MMP-9 was detected in the basement membrane of the corneal epithelium and related to diseases with conjunctival hyperemia, corneal neovascularization, epithelial erosions and corneal ulcerations ${ }^{(12)}$. High levels of MMP-9 may be responsible for the dissolution of basement membrane components such as hemidesmosomes, which may lead to migration and invasion of tumor cells ${ }^{(13)}$.

Pterygium lesion growth through the cornea and destruction of Bowman's membrane and superficial corneal stroma occur $^{(14)}$. Because of these facts we supposed to occur a similar process with overexpression of MMP-9 related to the genesis and progression of the pterygium.

Another fact which led us to study MMP-9 in pterygium lesion was the mast cell alterations already reported in pterygium $^{(15)}$ and the fact that neutrophils, macrophages and phagocytic cells overexpress MMP- ${ }^{(16)}$.

Although we did not observe MMP-9 overexpression in the pterygium lesion, according to others it was possible to have MMP-9 in the pterygium and in normal conjunctival tissue $^{(17)}$. The difference between these studies might be related to the used method. Our study and only another one ${ }^{(7)}$ about pterygium pathogenesis were done using "in vivo" samples but others used cultured cells which may not represent the true findings ${ }^{(18)}$.

Using cultured cells overexpression of MMP-1 and 3 at the head of pterygium was reported, but not expression of MMP2 or $9^{(5)}$
According to our results, primary and recurrent pterygium did not show any difference of MMP-9 expression. Probably recurrence is related to the incomplete lesion excision linked to proliferation of fibroblasts and production of MMP under the influence of inflammatory cytokines ${ }^{(19)}$.

Because of the overexpression of MMP in cultured fibroblasts $^{(18)}$ and the histologic characteristics of the pterygium (elastotic degeneration, fibroblast accumulation and fibrosis), the hypothesis of increasing enzymes that digest tissues provoking pterygium development may be seen with caution.

Theoretically, it seems more acceptable that if there is accumulation of substances in pterygium lesion this might be due to inhibitory active enzymes (TIMP) and not to increase in MMP.

Another suspicion might be that pterygium cells provoke activation of fibroblasts at the head of the lesion, leading to the initial cleavage of fibrillar collagen in Bowman's layer by the production of altered MMPs, a key role in the formation and migration of a pterygium ${ }^{(7)}$.

\section{CONCLUSION}

According to our results, MMP-9 expression is similar in Tenon's capsule from normal conjunctiva and from pterygium. Further studies must be conducted to investigate whether pterygium pathogenesis may be linked to MMP or TIMP.

\section{RESUMO}

Objetivo: Avaliar a expressão da metaloprotease de matriz (MMP)-9 nos pterígios. Métodos: Foi realizado na Faculdade de Medicina de Botucatu estudo prospectivo, aleatório, com o intuito de avaliar a expressão da metaloprotease de matriz na cápsula de Tenon normal e de pterígios primários e recidivados, usando o método da imuno-histoquímica e o sistema computadorizado de análise de imagem. Os resultados foram avaliados estatisticamente. Resultados: A expressão da metaloprotease de matriz foi semelhante na cápsula de Tenon normal e nos pterígios primários e recidivados. Conclusão: A expressão da metaloprotease de matriz na cápsula de Tenon normal e nos pterígios primários ou recidivados é semelhante, o que nos leva a concluir que esta metaloprotease de matriz não esteja envolvida na gênese ou na recidiva do pterígio.

\begin{tabular}{|c|c|c|c|}
\hline Primary & $\begin{array}{c}9931.7 \pm 3460.1 \\
(367.0 ; 25384.3)\end{array}$ & $\begin{array}{l}23.0 \pm 17.0 \\
(0 ; 161.0)\end{array}$ & $\begin{array}{c}0.003 \pm 0.002 \\
(0 ; 0.071)\end{array}$ \\
\hline Recurrent & $\begin{array}{c}11308.4 \pm 2876.9 \\
(2072.2 ; 19160.1)\end{array}$ & $\begin{array}{l}12.0 \pm 16.0 \\
(0 ; 310.0)\end{array}$ & $\begin{array}{c}0.002 \pm 0.002 \\
(0 ; 0.018)\end{array}$ \\
\hline Statistical Results & $\begin{array}{c}3.34 \\
(P>0.05)\end{array}$ & $\begin{array}{c}4.71 \\
(P>0.05)\end{array}$ & $\begin{array}{c}4.56 \\
(P>0.05)\end{array}$ \\
\hline
\end{tabular}


Descritores: Pterígio; Metaloproteinases da matriz; Imunohistoquímica/métodos; Recidiva

\section{REFERENCES}

1. Matrisian LM. Metalloproteinases and their inhibitors in matrix remodeling. Trends Genet. 1990;6(4):121-5.

2. Yip D, Ahmad A, Karapetis CS, Hawkins CA, Harper PG. Matrix metalloproteinase inhibitors: applications in oncology. Invest New Drugs. 1999; 17(4):387-99.

3. Li DQ, Meller D, Liu Y, Tseng S. Overexpression of MMP-1 and MMP-3 by cultured conjuntivochalasis fibroblasts. Invest Ophthalmol Vis Sci. 2000; 41(2):404-10.

4. Di Girolamo N, Lloyd A, McCluskey P, Filipic M, Wakefield D. Increased expression of matrix metalloproteinases in vivo in scleritis tissue and in vitro in cultured human scleral fibroblasts. Am J Pathol. 1997;150(2):653-66.

5. Solomon A, Li DQ, Lee SB, Tseng SC. Regulation of collagenase, stromelysin, and urokinase-type plasminogen activator in primary pterygium body fibroblasts by inflammatory cytokines. Invest Ophthalmol Vis Sci. 2000; 41(8):2154-63.

6. Di Girolamo N, McCluskey P, Lloyd A, Coroneo MT, Wakefield D. Expression of MMPs and TIMPs in human pterygea and cultured pterygium epithelial cells. Invest Ophthalmol Vis Sci. 2000;41(3):671-9.

7. Dushku N, John M, Schultz GS, Reid TW. Pterygia pathogenesis: corneal invasion by matrix metalloproteinase expressing altered limbal epithelial basal cells. Arch Ophthalmol. 2001;119(5):695-706. Erratum in: Arch Ophthalmol. 2002;120(2):234-7. Comment in: Arch Ophthalmol. 2002;120(2):234-7.

8. Nielsen BS, Sehested M, Kieldsen L, Borregaard N, Rygaard J, Dano K.
Expression of matrix metalloprotease- 9 in vascular pericytes in human breast cancer. Lab Invest. 1997;77(4):345-55.

9. Gown A M, Wever N, Battifora H. Microwave-based antigenic unmasking: a revolutionary new technique for routine immunohistochemistry. Appl Immunohistochem. 1993;3:256-66

10. Woessner JF Jr. Matrix metalloproteinases and their inhibitors in the connective tissue remodeling. FASEB J. 1991;5(8):2145-54.

11. Vu TH, Shipley JM, Bergers G, Berger JE, Helms JA, Hanahan D, et al. MMP-9/gelatinase B is a key regulator of growth plate angiogenesis and apoptosis of hypertrophic chondrocytes. Cell. 1998;93(3):411-22.

12. Afonso AA, Sobrin L, Monroy DC, Selzer M, Lokershwar B, Pflugfelder SC. Tear fluid gelatinase B - activity correlates with IL-1alpha concentration and fluorescein clearance in ocular rosacea. Invest Ophthalmol Vis Sci. 1999;40(11): 2506-12.

13. Stetler-Stevenson WG. Matrix metalloproteinases in angiogenesis: a moving target for therapeutic intervention. J Clin Invest. 1999;103(9):1237-41.

14. Cameron ME. Histology of pterygium: an electron microscopic study. Br J Ophthalmol. 1983;67(9):604-8.

15. Cilova-Atanasova B. The mastocyte reaction in pterygium. Folha Medica (Plovdiv). 1971;13:21-6.

16. Pfister H, Fuchs PG, Völcker HE. Human papillomavirus DNA in conjunctival papilloma. Graefes Arch Clin Exp Ophthalmol. 1985;223(3):164-7.

17. Li DQ, Lee S-B, Gunja-Smith Z, Liu Y, Solomon A, Meller D, et al. Overexpression of collagenase (MMP-1) and stromelysin (MMP-3) by pterygium head fibroblasts. Arch Ophthalmol. 2001;119(1):71-80.

18. Liu YP, Schultz GS, Ren XO, Tan DTH. MMP-2 and MMP-9 levels in pterygia and matched superior conjunctiva by gelatin zymography [abstract]. Invest Ophthalmol Vis Sci. 1998;39(5):S756.

19. Lee S-B, Li DQ, Gunja-Smith Z, Liu YQ, Tan DTH, Tseng SCG. Increased expression and activity of MMP-1 and MMP-3 by cultured pterygium head fibroblasts [abstract]. Invest Ophthalmol Vis Sci. 1999;40(2):S334.

\section{Simpósio da Associação Paranaense de Oftalmologia \\ III Congresso Sul-Brasileiro da SOBLEC \\ II Congresso Sul-Brasileiro de Claucoma \\ I Encontro Sul-Brasileiro de Visão Subnormal}

\section{2 a 24 de Junh॰ de 2006}

INFORMAC̣ÕES: Tel.: (41) 3232-4031

E-mail: apoftalmo@onda.com.br

Home-page: www.simposioapo.com.br 